International Journal of Agriculture, Environment and Bioresearch

Vol. 4, No. 04; 2019

ISSN: $2456-8643$

\title{
EFFECTS OF NITROGEN AND PHOSPHORUS FERTILISER RATES ON THE GROWTH RATE AND YIELD OF CASTOR BEAN (Ricinuscommunis [L.]) IN THE WET MIDDLEVELD OF ESWATINI
}

\author{
Mzwandile Petros Mabuza* and DelisileMabuza \\ Crop Production Department, Faculty of Agriculture, University of Eswatini, Luyengo, Eswatini, M205 \\ http://doi.org/10.35410/IJAEB.2019.4407
}

\begin{abstract}
In Eswatini, the production of castor bean is relatively low. This suggests that Emaswati have limited information on the production of castor bean. Most farmers know castor as a wild weed crop of less importance because of its low oil content compared to other agricultural oil crops. Therefore, this study had the objective of sensitizing farmers about the importance of castor bean and the recommended phosphorus and nitrogen fertiliser rates which are requisite towards achieving higher yields and especially higher oil content. A field experiment was conducted at the Crop Production Department experimental farm during the 2018/2019 cropping season. A randomized complete block design (RCBD) was used in the experiment. There were six treatment combinations ((1) Control, (2) $50 \mathrm{~kg} / \mathrm{ha} \mathrm{LAN,} \mathrm{(3)} 100 \mathrm{~kg} / \mathrm{ha} \mathrm{LAN,} \mathrm{(4)} \mathrm{Control,} \mathrm{(5)} 25$ $\mathrm{kg} / \mathrm{ha} \mathrm{P} 2 \mathrm{O} 5$ and (6) $50 \mathrm{~kg} / \mathrm{ha} \mathrm{P} 2 \mathrm{O} 5$ ). Results showed that nitrogen fertiliser applied at $100 \mathrm{~kg} / \mathrm{ha}$ had the highest seed yield of $64.5 \mathrm{~kg} / \mathrm{ha}$ and the lowest was $57.9 \mathrm{~kg} / \mathrm{ha}$ at $50 \mathrm{~kg} / \mathrm{ha}$. However the control of phosphorus had yield of $65.3 \mathrm{~kg} / \mathrm{ha}$. Also the results showed that application of phosphorus at $25 \mathrm{~kg} / \mathrm{ha}$ and $50 \mathrm{~kg} / \mathrm{ha}$ recorded the lowest yield of 50 and $48 \mathrm{~kg} / \mathrm{ha}$ respectively. There was no significant difference in the seed yield between the treatments. Nitrogen applied at $100 \mathrm{~kg} / \mathrm{ha}$ had the highest oil content of $1.6 \%$ compared to all the other treatments. The second highest oil content recorded was $1 \%$ of $25 \mathrm{~kg} / \mathrm{ha}$ of phosphorus fertiliser and the lowest recorded was $0.6 \%$ from the control of nitrogen fertiliser. Number of fruits per plant was insignificant and negatively correlated to oil content. The coefficient determination (R2) was $13.76 \%$. This shows a negligible contribution of the number of fruits per plant to oil content. The correlation coefficient oil percentage content to yield was not significantly different and it showed a very low coefficient determination (R2) of $10.50 \%$. The oil content to seed yield contributed only $10.50 \%$, which indicates a very low contribution. It is concluded that application of nitrogen fertiliser source LAN produced higher seed yield of $(60.9 \mathrm{~kg} / \mathrm{ha})$ compared to application of phosphorus fertiliser source P2O5 $(54.4 \mathrm{~kg} / \mathrm{ha})$, although it was not significant. Application of nitrogen fertiliser source LAN resulted to higher oil content of $(1.03 \%)$ than application of phosphorus with $(0.93 \%)$ oil content. It is recommended that $100 \mathrm{~kg} / \mathrm{ha}$ of LAN should be used because it gave a high seed yield and oil content.
\end{abstract}

Keywords: castor bean, seed yield, oil content, nitrogen, phosphorus.

\section{INTRODUCTION}


Castor bean (Ricinuscommunis L.) belongs to Euphorbiaceae family, common to all the warm regions of the world. It is a fast growing fibrous non wood plant native to eastern Africa, especially the Ethiopian area. This oil is highly viscous, its coloration ranges from a pale yellow to colourless, and it has a soft and faint odor and a highly unpleasant taste. Castor bean is grown as an annual in temperate zones and as a perennial in the tropics. This crop is cultivated for its seeds, which contain up to $45 \%$ of fast-drying natural oil rich in ricinoleic acid used mainly in medicines and industry(Hussein et al., 2015).

Castor bean (Ricinuscommunis L.) is an oleaginous (40-60\% oil) cultivated for its seeds which yield viscous, pale and non-volatile yellow oil (Villeneuveet al., 2005). The oil has many industrial applications notably it is used in the manufacture of paints, dyes, inks, waxes, varnishes, lubricants and brake fluids (Ogunniyi, 2006). The castor oil obtained by cold pressing of seeds is also used in household for soap production and as purgatives and laxatives (Weiss, 2000). Castor plant is cultivated industrially in many countries like India, China, Brazil, Madagasca(Villeneuveet al., 2005). However India alone exports $0.73 \mathrm{Mt}$ of castor seeds per year accounting to $60 \%$ of the total world production and therefore largely dominates the market. Despite the more and more increasing production, the demand for castor beans in the world market steadily increases (Sujatha et al., 2008), then given opportunity to improve and increase castor beans production. In this respect Reddyand Matcha(2010) suggested that castor bean crop can become a cash crop in modern agriculture. Studies have been initiated in this direction to introduce and study the adaptability of castor bean in different soil of several countries including USA (Baldwin and Cossar, 2009) and in Europe (Armendárizet al., 2015).

In Eswatini, the production of castor bean is relatively low. This suggests that Emaswati have less information on the production of castor bean. Most farmers know castor as a wild weed crop and of less importance, because of its low oil content compared to other agricultural crops. Therefore, this study seeks to sensitise farmers about the importance of castor bean and the recommended phosphorus and nitrogen fertiliser rates which are requisite towards achieving higher yields.

In an experiment conducted by Sondarva (2012), he discovered that an application of 100kg/ha of nitrogen recorded significantly higher plant height $(78.16,114.64$ and $132.28 \mathrm{~cm}$ at 60 days after planting and harvest respectively, number of branches per plant $(9,55)$,number of internodes up to spikes per plant (10.60),seed weight per plant (109.61g),weight of 100 seeds $(33.19 \mathrm{~g})$,seed yield $(26.60 \mathrm{~g} / \mathrm{ha})$ and stalk yield $(32.92 \mathrm{~g} / \mathrm{ha})$.Similarly, the crop fertilised with $100 \mathrm{~kg} / \mathrm{ha}$ recorded significantly higher oil content $(12.73 \mathrm{q} / \mathrm{ha})$, nitrogen content in seed $(0.705 \%)$ and stalk $(0.475 \%)$,nitrogen uptake by seed $(19.15 \mathrm{~kg} / \mathrm{ha})$ and stalk $(14.88 \mathrm{~kg} / \mathrm{ha})$ and available $\mathrm{N}$ in the soil $(285.11 \mathrm{~kg} / \mathrm{ha})$. The application of $50 \mathrm{~kg} / \mathrm{ha}$ of phosphorus recorded significantly higher plant height $(78.13,112.74$ and $133.31 \mathrm{~cm}$ at 60 ,90 days after planting and at harvest),number of branches per plant (8.68),length of main spike $(39.29 \mathrm{~cm})$,number of capsules per main spike (57.45), seed weight per plant (108.73g) and 100 seed weight $(32.94 \mathrm{~g})$,seed yield(25.55q/ha) and stalk yield (31.87 q/ha),phosphorus content in the seed $(0.354 \%)$ and stalk $(0.236 \%)$, phosphorus uptake by seed $(8.93 \mathrm{~kg} / \mathrm{ha})$ and stalk $(7.34 \mathrm{~kg} / \mathrm{ha})$ and phosphorus availability $(38.98 \mathrm{~kg} / \mathrm{ha})$ in soil. Interaction effect of application of $75 \mathrm{~kg} / \mathrm{ha} \mathrm{N}$ and $50 \mathrm{~kg} / \mathrm{ha} \mathrm{p}$ recorded significantly higher number of branches per plant (10.41). Therefore it can be inferred that better crop yield with 
higher net can be obtained from castor by fertilizing the crop with $100 \mathrm{~kg} / \mathrm{ha} \mathrm{N}$ an $50 \mathrm{~kg} / \mathrm{ha} \mathrm{P}$ in the medium black calcareous soil of South Saurashtra Agro climatic region.

\section{MATERIALS AND METHODS}

\section{Experimental site and treatments}

This experiment was conducted at the Crop Production Department experiment farm P 19, Faculty of Agriculture, University of Eswatini, which is in the Middleveld agro-ecological zone of Eswatini and $750 \mathrm{~m}$ above sea level. Mean annual rainfall range is $800 \mathrm{~mm}$ and mean annual temperature of $18^{\circ} \mathrm{C}$ (Edje and Ossom, 2009). The randomized complete block design (RCBD) in a factorial arrangement was used in this experiment, there were six treatments combinations and replicated three times (Table 1).

Table 1.Treatment codes and description of the experiment

\begin{tabular}{|ll|}
\hline Treatment code & Treatment description \\
\hline 1 & Control \\
2 & $50 \mathrm{~kg} / \mathrm{ha} \mathrm{LAN}$ \\
3 & $100 \mathrm{~kg} / \mathrm{ha} \mathrm{LAN}$ \\
\hline 4 & Control \\
5 & $25 \mathrm{~kg} / \mathrm{ha} \mathrm{P}_{2} \mathrm{O}_{5}$ \\
6 & $50 \mathrm{~kg} / \mathrm{ha} \mathrm{P}_{2} \mathrm{O}_{5}$ \\
\hline
\end{tabular}

\section{Plot sizes}

A total of 18 plots were used to conduct the experiment, each plot was measuring $4.5 \mathrm{~m}$ by $10 \mathrm{~m}$ and three rows per plot, a tape measure, set of pegs and a string were used to mark the plots. The inter-row spacing was $1.5 \mathrm{~m}$ and the intra-row spacing of $1 \mathrm{~m}$ for every treatment. Each row had ten plants, which will make a total number of thirty plants per plot.

\section{Soil analysis}

Soil samples were collected from the experimental site and taken to the Chemistry laboratory for determination of the basic properties of the soil including $\mathrm{pH}$, phosphorus, Nitrogen, Potassium, exchangeable Aluminium, Calcium and Magnesium.

\section{Planting}

Planting was done on the $4^{\text {th }}$ of November 2018.Application of single superphosphate and LAN fertilisers was applied four weeks after planting at rates of $0 \mathrm{~kg} / \mathrm{ha}, 50 \mathrm{~kg} / \mathrm{ha}, 100 \mathrm{~kg} / \mathrm{ha}$. Single superphosphate was also applied at $0 \mathrm{~kg} / \mathrm{ha}, 25 \mathrm{~kg} / \mathrm{ha}$ and $50 \mathrm{~kg} / \mathrm{ha}$. 


\section{Weeding}

Good weed control is essential for good castor development. In the first stages of castor emergence and establishment, which is very slow, the plants are very vulnerable to weed competition. It is imperative to keep the plot weed-free. Weeding was done manually, using a hoe at five and 12 weeks after planting.

\section{Leaf area index}

Length of the central leaflet was measured and leaf width was taken from the widest part of the leaf, both parameters were measured using a $3 \mathrm{~m}$ tape measure. The leaf area was calculated using the formula, Leaf area=length of central leaflet ${ }^{*} 6.11$ provided in the Crop science book written by (Edje and Ossom, 2009).From the leaf area leaf area index was calculated using the formula: LAI $=$ Leaf area $/$ land area

\section{Number of fruits per plant}

Fruits were counted and recorded per plant from the five plants used to collect data from the middle row, just after they have started fruiting.

\section{Shelling percentage}

The shelling percentage was recorded in all the treatments, using the formula, shelling $\%=$ dry mass of shelled/dry mass of unshelled $* 100$.

\section{Mass of 100 seeds}

A total of 100 seeds per treatment were counted. These seeds were first weighed for fresh mass and then oven dried for 72 hours at $100^{\circ} \mathrm{C}$ before taking their mass after oven drying.

\section{Seed yield (kg/ha) at $8 \%$ moisture content}

The seed yield was determined from the harvested area and calculated using the formula

Seed yield $=\underline{\text { net }}$ plot fresh mass $\mathrm{x}$ factor (10) x100-moisture content at harvesting

(100-desired moisture content) $\mathrm{x}$ net plot area $\left(\mathrm{m}^{2}\right)$

\section{Percentage Oil content}

The seeds were sun dried first to remove moisture, and this aided in extraction of the oil. The percentage oil content was determined using the Soxhlet extraction method. In the Soxhlet extraction method oil is extracted, semi-continously, with an organic solvent which was cyclohexane. 


\section{Data analysis}

Data collected was subjected in MS excel and subsequently analysed using Genstat statistical package $15^{\text {th }}$ edition. The mean separation was done using Duncan's New Multiple Range Test (DNMRT) at 5\% level of probability.

\section{RESULTS}

Lear area index ranged from two to three at 8 weeks after planting for the treatments. As the weeks after planting progressed the leaf area index increased at an increasing rate of 2.3 to 3.2 at 10 weeks after planting. At week 12, the treatment of $100 \mathrm{~kg} / \mathrm{ha}$ of LAN had the least leaf area index of 2.5 (Table 2).

Table 2. Leaf Area Index at 8, 10, 12, 14 and 16 weeks after planting

\begin{tabular}{|llllll|}
\hline Treatments & $8 \mathrm{WAP}$ & $10 \mathrm{WAP}$ & $12 \mathrm{WAP}$ & $14 \mathrm{WAP}$ & $16 \mathrm{WAP}$ \\
\hline Control & $2.1 \mathrm{a}$ & $2.39 \mathrm{a}$ & $2.52 \mathrm{a}$ & $2.8 \mathrm{a}$ & $2.8 \mathrm{a}$ \\
$50 \mathrm{~kg} / \mathrm{ha} \mathrm{LAN}$ & $2.55 \mathrm{a}$ & $2.87 \mathrm{a}$ & $2.97 \mathrm{a}$ & $3.07 \mathrm{a}$ & $3.07 \mathrm{a}$ \\
$100 \mathrm{~kg} / \mathrm{ha} \mathrm{LAN}$ & $2.51 \mathrm{a}$ & $2.68 \mathrm{a}$ & $2.4 \mathrm{a}$ & $2.49 \mathrm{a}$ & $2.49 \mathrm{a}$ \\
$\mathrm{Control}$ & $2.97 \mathrm{a}$ & $3.18 \mathrm{a}$ & $3.77 \mathrm{a}$ & $3.89 \mathrm{a}$ & $3.89 \mathrm{a}$ \\
$25 \mathrm{~kg} / \mathrm{ha} \mathrm{P}_{2} \mathrm{O}_{5}$ & $2.43 \mathrm{a}$ & $2.56 \mathrm{a}$ & $2.52 \mathrm{a}$ & $2.7 \mathrm{a}$ & $2.7 \mathrm{a}$ \\
$50 \mathrm{~kg} / \mathrm{ha}_{2} \mathrm{O}_{5}$ & $2.85 \mathrm{a}$ & $3.13 \mathrm{a}$ & $3.03 \mathrm{a}$ & $3.34 \mathrm{a}$ & $3.34 \mathrm{a}$ \\
Significance & $\mathrm{NS}$ & $\mathrm{NS}$ & $\mathrm{NS}$ & $\mathrm{NS}$ & NS \\
CV \% & 20.5 & 18.3 & 21.4 & 21.2 & 21.2 \\
\hline
\end{tabular}

Mean values with the same alphabet in a column are not significantly different from each other according to Duncan's New Multiple Range Test $(\mathrm{DNMRT})$ at $(\mathrm{P}<0.05)$ probability level. $\mathrm{CV}=$ coefficient of variation, NS = not significant

There was no significant difference in the shelling percentage between the treatments. However, $100 \mathrm{~kg} / \mathrm{ha}$ LAN and the control of phosphorus had highest values of $92.7 \%$ and $93.7 \%$, the lowest being $78.3 \%$ with $50 \mathrm{~kg} / \mathrm{ha}$ of phosphorus fertiliser (Table 3 ).

Table 3.Shelling Percentage (\%)

\begin{tabular}{|lll|}
\hline Treatments & Shelling \% & Means \\
\hline Control & $87.3 \mathrm{a}$ & \\
$50 \mathrm{~kg} / \mathrm{ha} \mathrm{LAN}$ & $83.7 \mathrm{a}$ & \\
$100 \mathrm{~kg} / \mathrm{ha} \mathrm{LAN}$ & $92.7 \mathrm{a}$ & $87.9 \mathrm{a}$ \\
Control & $93.7 \mathrm{a}$ & \\
$25 \mathrm{~kg} / \mathrm{ha} \mathrm{P}_{2} \mathrm{O}_{5}$ & $81.3 \mathrm{a}$ & \\
$50 \mathrm{~kg} / \mathrm{ha} \mathrm{P}_{2} \mathrm{O}_{5}$ & $78.3 \mathrm{a}$ & $84.4 \mathrm{a}$ \\
Significance & $\mathrm{NS}$ & \\
$\mathrm{CV} \%$ & 14.5 & 14.5 \\
\hline
\end{tabular}


Mean values with the same alphabet in a column are not significantly different from each other according to Duncan's New Multiple Range Test $(\mathrm{DNMRT})$ at $(\mathrm{P}<0.05)$ probability level. $\mathrm{CV}=$ coefficient of variation, $\mathrm{NS}=$ not significant

Nitrogen fertiliser applied at rate of $100 \mathrm{~kg} / \mathrm{ha}$ had the highest mass of $47.66 \mathrm{~g}$ and rate of 50 $\mathrm{kg} / \mathrm{ha}$ had 47.22g.Phosphorus fertiliser control and rate of $50 \mathrm{~kg} / \mathrm{ha}$ showed the lowest mass of $45.09 \mathrm{~g}$ and $44.9 \mathrm{~g}$ respectively. A total of 100 seeds per treatment was recorded and analyzed. There was no significant difference in the mass of 100 seeds across all the treatments (Table 4).

Table 4. Mass of 100 seeds

\begin{tabular}{|lll|}
\hline Treatments & Mass of $100 \operatorname{seeds}(\mathrm{g})$ & Means \\
\hline Control & $45.66 \mathrm{a}$ & \\
$50 \mathrm{~kg} / \mathrm{ha} \mathrm{LAN}$ & $47.22 \mathrm{a}$ & \\
$100 \mathrm{~kg} / \mathrm{ha} \mathrm{LAN}$ & $47.66 \mathrm{a}$ & $46.85 \mathrm{a}$ \\
\hline $\mathrm{Control}$ & $45.09 \mathrm{a}$ & \\
$25 \mathrm{~kg} / \mathrm{ha} \mathrm{P}_{2} \mathrm{O}_{5}$ & $46.54 \mathrm{a}$ & $45.51 \mathrm{a}$ \\
$50 \mathrm{~kg} / \mathrm{ha} \mathrm{P}_{2} \mathrm{O}_{5}$ & $44.9 \mathrm{a}$ & \\
Significance & $\mathrm{NS}$ & 4.6 \\
CV $(\%)$ & 4.6 & 48 \\
\hline
\end{tabular}

Mean values with the same alphabet in a column are not significantly different from each other according to Duncan's New Multiple Range Test $(\mathrm{DNMRT})$ at $(\mathrm{P}<0.05)$ probability level. $\mathrm{CV}=$ coefficient of variation, $\mathrm{NS}=$ not significant

Nitrogen fertiliser had the highest yield of $426 \mathrm{~kg} / \mathrm{ha}$ and phosphorus was lower with381 $\mathrm{kg} / \mathrm{ha}$.However, the control of phosphorus had a yield of $457 \mathrm{~kg} / \mathrm{ha}$, while the application of phosphorus at rates of $25 \mathrm{~kg} / \mathrm{ha}$ and $50 \mathrm{~kg} / \mathrm{ha}$ had the lowest recorded yields of 350 and 336 $\mathrm{kg} / \mathrm{ha}$, respectively.There was no significant differences in the seed yield across all treatments(Table 5).

Table 5. Seed yield ( $\mathrm{kg} / \mathrm{ha})$ at $8 \%$ moisture content

\begin{tabular}{|lll|}
\hline Treatments & Yield $(\mathrm{kg} / \mathrm{ha})$ & Means \\
\hline Control LAN & $421 \mathrm{a}$ & \\
$50 \mathrm{~kg} / \mathrm{ha} \mathrm{LAN}$ & $405 \mathrm{a}$ & $426 \mathrm{a}$ \\
$100 \mathrm{~kg} / \mathrm{ha} \mathrm{LAN}$ & $452 \mathrm{a}$ & \\
Control P2O5 & $457 \mathrm{a}$ & \\
$25 \mathrm{~kg} / \mathrm{ha} \mathrm{P}_{2} \mathrm{O}_{5}$ & $350 \mathrm{a}$ & $381 \mathrm{a}$ \\
$50 \mathrm{~kg} / \mathrm{ha} \mathrm{P}_{2} \mathrm{O}_{5}$ & $336 \mathrm{a}$ & \\
Significance & NS & 13.5 \\
$\mathrm{CV}(\%)$ & 13.5 & \\
\hline
\end{tabular}


Mean values with the same alphabet in a column are not significantly different from each other according to Duncan's New Multiple Range Test (DNMRT) at $(\mathrm{P}<0.05)$ probability level. $\mathrm{CV}=$ coefficient of variation, $\mathrm{NS}=$ not significant

There was no significant difference in the percentage oil content at dry weigh basis between the treatments. However nitrogen applied at a rate of $100 \mathrm{~kg} / \mathrm{ha}$ had the highest oil content of $22.4 \%$ compared to all the other treatments. The second highest oil content recorded was $14.0 \%$ of 25 $\mathrm{kg} / \mathrm{ha}$ of phosphorus fertiliser and the lowest recorded was $8.4 \%$ being the control of nitrogen fertiliser. (Table 6).

Table 6. Oil content (\%)

\begin{tabular}{|lll|}
\hline Treatment & \% oil on dry weigh basis & Means \\
\hline Control & 8.4 & \\
$50 \mathrm{~kg} / \mathrm{ha} \mathrm{LAN}$ & $12.6 \mathrm{a}$ & \\
$100 \mathrm{~kg} / \mathrm{ha} \mathrm{LAN}$ & $22.4 \mathrm{a}$ & $14.5 \mathrm{a}$ \\
\hline Control & $13.5 \mathrm{a}$ & \\
$25 \mathrm{~kg} / \mathrm{ha} \mathrm{P}_{2} \mathrm{O}_{5}$ & $14.0 \mathrm{a}$ & \\
$50 \mathrm{~kg} / \mathrm{ha} \mathrm{P}_{2} \mathrm{O}_{5}$ & $11.7 \mathrm{a}$ & $13.1 \mathrm{a}$ \\
Significance & $\mathrm{NS}$ & \\
$\mathrm{CV}(\%)$ & 60.4 & 60.4 \\
\hline
\end{tabular}

Mean values with the same alphabet in a column are not significantly different from each other according to Duncan's New Multiple Range Test (DNMRT) at $(\mathrm{P}<0.05)$ probability level. $\mathrm{CV}=$ coefficient of variation, $\mathrm{NS}=$ not significant

Table 7. Correlation coefficient matrix of some castor bean parameters

\begin{tabular}{|c|c|c|c|c|c|c|c|c|c|c|}
\hline Parameter & STC & SY & $\mathrm{S} \%$ & D & $\mathrm{OC}$ & NB & NF & $\mathrm{H}$ & LA & LAI \\
\hline $\begin{array}{l}\text { Seed } \\
\text { yield }\end{array}$ & $\overline{0} 196^{\mathrm{NS}}$ & & & & & & & & & \\
\hline Shelling & - & & & & & & & & & \\
\hline$\%$ & $0.137^{\mathrm{NS}}$ & $0.889^{* *}$ & & & & & & & & \\
\hline Diameter & $-0.558^{*}$ & $0.373^{\mathrm{NS}}$ & $0.417^{\mathrm{NS}}$ & & & & & & & \\
\hline Oil & - & & & & & & & & & \\
\hline content & $\begin{array}{l}0.259^{\mathrm{NS}} \\
-\end{array}$ & $0.324^{\mathrm{NS}}$ & $0.361^{\mathrm{NS}}$ & $0.43^{*}$ & & & & & & \\
\hline Branches & $0.374^{\mathrm{NS}}$ & $0.345^{\mathrm{NS}}$ & $0.49^{*}$ & $0.83^{* *}$ & $0.324^{\mathrm{NS}}$ & & & & & \\
\hline Fruit No. & $0.346^{\mathrm{NS}}$ & $0.311^{\mathrm{NS}}$ & $0.506^{*}$ & $0.53^{*}$ & $0.371^{\mathrm{NS}}$ & $0.58^{*}$ & & & & \\
\hline Height & $\begin{array}{l}-0.672^{*} \\
-\end{array}$ & $0.254^{\mathrm{NS}}$ & $0.326^{\mathrm{NS}}$ & $0.9^{* *}$ & $0.408^{\mathrm{NS}}$ & $0.798^{* *}$ & $0.55^{*}$ & & & \\
\hline LA & $0.358^{\mathrm{NS}}$ & $0.444^{\mathrm{NS}}$ & $0.399^{\mathrm{NS}}$ & $0.7^{* *}$ & $0.479^{*}$ & $0.617^{* *}$ & $0.61^{*}$ & $0.58^{*}$ & & \\
\hline $\begin{array}{l}\text { LAI } \\
\text { Nodes }\end{array}$ & $-0.535^{*}$ & $0.382^{\mathrm{NS}}$ & $0.425^{*}$ & $0.86^{* *}$ & $0.554^{*}$ & $0.758^{* *}$ & $0.66^{* *}$ & $0.8^{* *}$ & $0.88^{* *}$ & \\
\hline No. & $0.151^{\mathrm{NS}}$ & $0.217^{\mathrm{NS}}$ & $0.206^{\mathrm{NS}}$ & $0.42^{\mathrm{NS}}$ & $0.188^{\mathrm{NS}}$ & $0.162^{\mathrm{NS}}$ & $0.27^{\mathrm{NS}}$ & $0.18^{\mathrm{NS}}$ & $0.54^{*}$ & $0.5^{*}$ \\
\hline
\end{tabular}


*Significant at $\mathrm{P}<0.05 \quad * *$ Significant at $\mathrm{P}<0.01 \quad \mathrm{NS}=$ not significant

$\mathrm{STC}=$ stem colour; $\mathrm{D}=$ diameter $\mathrm{OC}=$ oil content; $\mathrm{NB}=$ number of branches; $\mathrm{NF}=$ number of fruits; $\mathrm{H}=$ height; LA =leaf area; LAI=leaf area index; $\mathrm{NN}=$ number of nodes; $\mathrm{SY}=$ seed yield; $\mathrm{S} \%=$ shelling percentage

\section{DISCUSSION}

\subsection{Leaf area index}

The results showed that there were no significant differences in leaf area index for both two different fertilisers applied as well as the three different rates. Nitrogen and phosphorus did not have an effect on leaf area index. Maximum leaf area index of 3.89 was recorded at 14 and 16 weeks after planting on the control of phosphorus fertiliser and the least leaf area index of 2.10 was obtained at 8 weeks after planting with the control of nitrogen. On week 16after planting the control of phosphorus had the highest leaf area index.

\subsection{Shelling percentage}

As one would expect, shelling percentage did not show any significant differences across all treatments. The control for phosphorus has shown to have the greater shelling percentage of $93.7 \%$ among all the treatments, followed by application of $100 \mathrm{~kg} / \mathrm{ha}$ with $92.7 \%$.The least shelling percentage was recorded was $78.3 \%$ at $50 \mathrm{~kg} / \mathrm{ha} \mathrm{P}_{2} \mathrm{O}_{5}$.

\subsection{Mass of 100 seeds}

A total of 100 seeds per treatment were recorded. These seeds were first weighed their fresh mass and then oven dried for 72 hours at $100^{\circ} \mathrm{C}$ before taking their weight after oven drying. These seeds were first weighed fresh mass then oven dried for 72 hours before taking the weight. The maximum mass of 100 seeds recorded was $47.66 \mathrm{~g}$ at $100 \mathrm{~kg} / \mathrm{ha}$ of nitrogen fertiliser and the minimum mass was $44.90 \mathrm{~g}$ at $50 \mathrm{~kg} / \mathrm{ha} \mathrm{P}_{2} \mathrm{O}_{5}$. These finding are in agreement with Duke (1983), who reported 120.8 to $530.2 \mathrm{~g}$ thousand seed weight using different nitrogen doses and various local castor bean varieties. Contrarily, Shams et al. (1967) reported lesser thousand seed weights in castor bean plant which might be due to different plant material and environmental conditions in this study. There was no significant difference in the mass of 100 seeds. This may be as a result that seed size is an inherited characteristic.

\subsection{Seed yield (kg/ha) at $8 \%$ moisture content.}

The net plot for all the treatments was based on the total area harvested which was $45 \mathrm{~m}^{2}$ per plot and each plot had either nitrogen or phosphorus fertiliser at the different rates used. There was a slight increase in yield with100 kg/ha $\mathrm{LAN}$ and control of $\mathrm{P}_{2} \mathrm{O}_{5}$. Seed yield fertiliser means showed that application of nitrogen fertiliser recorded the highest yield of $(426 \mathrm{~kg} / \mathrm{ha})$ and application of phosphorus recorded the lowest yield of $(381 \mathrm{~kg} / \mathrm{ha})$ respectively. This can be due to the fact that more application of nitrogen provided sufficient supply of resources. Maryam $e t$ al. (2012) reported that the maximum seed yield $(3108 \mathrm{~kg} /$ ha was obtained from LV5 with 100 $\mathrm{kg} / \mathrm{ha}$ nitrogen. Whereas, minimum seed yield $(1614 \mathrm{~kg} / \mathrm{ha})$ was recorded in LV3 at control (0 $\mathrm{kg} / \mathrm{ha} \mathrm{N}$ ). Furthermore, seed yield was significantly affected by different local castor bean 
varieties $(\mathrm{P} \leq 0.01)$ and the highest seed yield was $2566 \mathrm{~kg} / \mathrm{ha}$ from LV 5. The low seed yield in this experiment could be attributed to the fact that the plants were still fruiting when this report was being compiled.

\subsection{Percentage (\%) oil content at dry weigh basis}

There was no significant difference in the percentage oil content in all the treatments, however application of $100 \mathrm{~kg} / \mathrm{ha}$ showed to have the highest oil content of $22.4 \%$ among all the other treatments. The lowest oil content of $8.4 \%$ was extracted from the control of nitrogen. The results showed that nitrogen and phosphorus had no effect on the oil content of castor bean. Maryam (2012) discovered that crude oil ratio was affected by none of the growth parameters. In her study, the crude oil content varied between 35.3 and $51.4 \%$ among interaction of LV and nitrogen doses. LV means ranged from 40.6 to $46.6 \%$ whereas; nitrogen doses ranged 40.9 to $44.5 \%$. In general, high nitrogen rates reduced oil content at all oil crops (Malidarreh, 2010). In some similar studies, the amount of crude oil in different castor bean cultivars were between 50 and $60 \%$ (Shams et al. (1967); Armstrong (1982) and Brigham (1993). On the other hand,Deligianniset al. (2009) in a research obtained $40.3 \%$ oil in castor bean cultivars.

The low amount of oil content extracted might be a result that the crushed samples were stored in the refrigerator for a long period of time before extracting the oil. This long period of time spent by the samples in the refrigerator was caused by the unavailability of the Soxhlet apparatus, since other researchers were also using it for their experiments. For the extraction of oil, the seeds were sun dried first to remove moisture, and this aided in extraction of the oil. The percentage oil content was determined using the Soxhlet extraction method. In this method oil is extracted, semi-continously, with an organic solvent which was cyclohexane.

\subsection{Correlations}

The correlation coefficient of shelling percentage to seed yield was highly significant $(\mathrm{P}<0.01)$ and the coefficient determination $\left(\mathrm{R}^{2}\right)$ of shelling percentage to seed yield was $79.03 \%$. This indicates that shelling percentage and seed yield had a strong correlation and that shelling percentage contributed significantly to seed yield. Stem diameter and yield were not significantly correlated with a coefficient of determination $\left(\mathrm{R}^{2}\right)$ of $13.91 \%$. This indicates thatonly $13.91 \%$ of the variation in seed yield could be attributed to differences in stem diameter. The correlation coefficient of percentage oil content to yield was also not significant and had a very low coefficient determination $\left(\mathrm{R}^{2}\right)$ of $10.50 \%$. This indicates that only $10.50 \%$ of the differences in oil content could be attributed to seed yield

As would be expected, the correlation coefficient between number of fruits and shelling percentage was highly significant $(\mathrm{P}<0.01)$ and the coefficient determination was $25.60 \%$, thus indicating that the number of fruits is responsible for $25.06 \%$ of the variations in shelling percentage.The correlation of number of fruits to number of branches was also highly significant $(\mathrm{P}<0.01)$.However, the coefficient of determination $\left(\mathrm{R}^{2}\right)$ was $33.64 \%$ and this shows a low contribution of number of branches to number of fruits. 


\section{REFERENCES}

Armendáriz, J., Lapuerta, M., Zavala, F., García-Zambrano, E. anddel Carmen Ojeda, M. (2015). Evaluation of eleven genotypes of castor oil plant (Ricinuscommunis L.) for the production of biodiesel. Industrial Crops and Products, 77, 484-490.

Duke, J. A. (1983). Ricinuscommunis L. https://www.hort.purdue.edu/newcrop/duke_energy/Ricinus_communis.html. 25/04/2019.

Baldwin, B. S.andCossar, R. D. (2009). Castor yield iandn response to planting date at four locations in the south-central United States. Industrial Crops and Products, 29(23), 316-319.

Bringham, R. D.and Spears, B. R. (1960). Castor Beans in Texas. Texas Farmer Collection.

Deligiannis , A., Anastopoulos, G. and Karavalakis, G. (2009).Castor (RicinusCommunis L.) seed oil as an alternative feedstock for the production of biodiesel. Proceedings of the 11th International Conference on Environmental Science and Technology Chania, Crete, Greece, 3 - 5 September 2009.

Edje, O. T.andOssom, E. M. (2009). Crop Science Handbook. Blue Moon Printers, Manzini, Swaziland.

Hussein, M. M., El-Saady, A. M.andAbou-Baker, N. H. (2015). Castor bean plants response tophosphorus sources under irrigation by diluted seawater. International Journal ChemecalTechnolgy Research, 8(9), 261-271.

Malidarreh, A. (2010). Effects of Nitrogen Rates and Splitting on Oil Content and Seed Yield of Canola (Brassica napus L.). American-Eurasian Journal of Agriculture \& Environmental Science, 8 (2): 161-166.

Maryam, B., Payam, P. and Hadis, N. (2012). Study the effect of nitrogen, phosphorus and bio-fertilizer vermicompost on yield and yield components of lentil in autumn and spring sowing in rain fed conditions of Khorramabad,Iran. Annals of Biological Research, 2012, 3 (12):5644-5646.

Ogunniyi, D. S. (2006). Castor oil: a vital industrial raw material. Bioresource technology, 97(9), 1086-1091.

Shams, A., Moursi, M. A., Ahmed, S.S., 1967. Effects of nitrogen and spacing on castor bean in sandy soils in Egypt. Cairo University. U.A.R. National Research Centre and Faculty of Agriculture, pp. 61-64. 
Villeneuve, P., Lago, R., Barouh, N., Barea, B., Piombo, G., Dupré, J. Y. and Pina, M. (2005). Production of conjugated linoleic acid isomers by dehydration and isomerization of castor bean oil. Journal of the American Oil Chemists' Society, $\quad 82(4), \quad$ 261-269.

Reddy, K. R. andMatcha, S. K. (2010). Quantifying nitrogen effects on castor bean (Ricinus communis L.) development, growth, and photosynthesis. Industrial Crops and products, 31(1), 185-191.

Sondarva, M. K. (2012). Effect of nitrogen, phosphorus and sulphur on growth and yield of summer castor [Ricinuscommunis (L.)] (Doctoral dissertation, jau, junagadh).

Sujatha, M., Reddy, T. P., andMahasi, M. J. (2008). Role of biotechnological interventions in the improvement of castor (Ricinuscommunis L.) and Jatropha curcas L. Biotechnology advances, 26(5), 424-435.

Villeneuve, P., Lago, R., Barouh, N., Barea, B., Piombo, G., Dupré, J. Y. and Pina, M. (2005). Production of conjugated linoleic acid isomers by dehydration and isomerization of castor bean oil. Journal of the American Oil Chemists' Society, 82(4), 261-269.

Weiss, E. A. (2000). Castor Oilseed Crops. UK Blackwell Science, 13-52. 